\title{
CONCEPT OF 'YAMDANSHTRA' IN AYURVED AND RISE IN CASES OF COVID 19 PANDEMIC
}

\author{
Dr. Nishi Arora ${ }^{1}$, Dr. Nidhi Shrivastava ${ }^{2}$ and Ravi Shrivastav ${ }^{3}$ \\ ${ }^{1}$ Associate Professor, Maulik Siddhant and Samhita Vibhag, A\&U Tibbia College and Hospital, New Delhi, India \\ ${ }^{2}$ Associate Professor and Head of Department, Sharir Rachna Vibhag, Government Ayurveda College, Jabalpur, Madhya \\ Pradesh, India \\ ${ }^{3}$ Associate Professor and Head of Department, Agad Tantra \& Vyavhar Ayurveda Vibhag, Government Ayurveda College, \\ Jabalpur, Madhya Pradesh, India
}
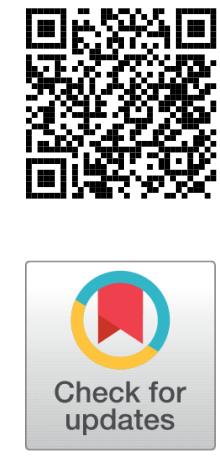

Received 3 April 2021

Accepted 18 April 2021

Published 30 April 2021

Corresponding Author

Dr. Nishi Arora, nishiarora_doc@y

ahoo.do.in

DOI $10.29121 /$

granthaalayah.v9.i4.2021.3889

Funding: This research received no specific grant from any funding agency in the public, commercial, or not-for-profit sectors.

Copyright: (C) 2021 The Author(s). This is an open access article distributed under the terms of the Creative Commons Attribution License, which permits unrestricted use, distribution, and reproduction in any medium, provided the original author and source are credited.

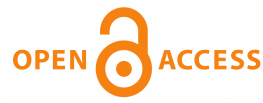

\section{ABSTRACT}

Upon observation of the steep rise in Covid cases patients all over the world, it seems to be clear that along with conventional methods for prevention and cure of this unpredictable disease, something more requires employment. This paper proposes that the concept of 'Yamdanshtra' (described in Sharangdhar Samhita) "Shaaranghar Samhita Ch-3/29" (2021) / "Ritusandhi"(described in Charak Samhita) "Charak Samhita Tasyaashiteadhyaya/48 Chakrapaani" (2021) is a viable solution. A specific 'diet modification pattern'(Padanshik Tyag vidhi) is recommended for better immunity. Detailed graphical studies have been shown about relationship of the number of cases of Covid and the periods of Yamdanshtra or Ritusandhi(cusp between two seasons) in Bharat and three more countries viz. USA,UK and Russia. It was concluded in the study that a positive relation between Covid cases and transition periods can be established. In countries other than Bharat, the rise in Covid cases was present but not significant. It is hypothesized that that may be because the seasons do not show much difference in climatic conditions or in other parameters. For Bharat, the Padanshik Tyag "Charak Samhita Navegaandhaaraniya/36-37" (2021) method of diet modification during transition periods may work,while other countries may prefer taking a lighter diet during them.

Keywords: Yamdanshtra, Ritusandhi, Padanshik, Tyag, Yam

\section{INTRODUCTION}

The whole world is struggling to come out from the grave situation arisen out of Pandemic Covid 19 or Corona infection. The last year was a nightmare for many.But, unfortunately in this year also the virus has come up with new mutants. All the countries including Bharat are facing the worst again. The modern researchers are 
trying their level best to know more and more about the virus,so that they may find out some convincing solution.Wearing mask,maintaining social distancing,avoiding crowds are some of the effective ways,the human community can follow to prevent it from this monster.In this scenario,the Ancient science of Ayurved may play a positive

role in combating this challenge.Ayurved not only says that "prevention is better than cure"but also guides about the ways of prevention from diseases in general.

In the above said context,an important concept of 'Yamdanshtra'has been discussed in the following paper.The term is used for fourteen/sixteen days transition period between the two seasons I.e.the period that includes last seven days of the passing season and first week of the upcoming season.

\section{MATERIAL AND METHODS}

The term Yamdanshtra was explored for its varied meanings. The other term which is used for this is Ritusandhi by Achary Charak. It was also read to interpret for the purpose. Concept of Padanshik tyag was also explored. Sharangdhar Samhita was referred to understand it from another perspective.

Data was collected over site of BBC to know about relation between the surge of Covid 19 cases and the transition period (the period of union of the two seasons) in four countries (Bharat-USA- Britain-Russia).

\section{DISCUSSION}

- Status of United states of America in COVID time:
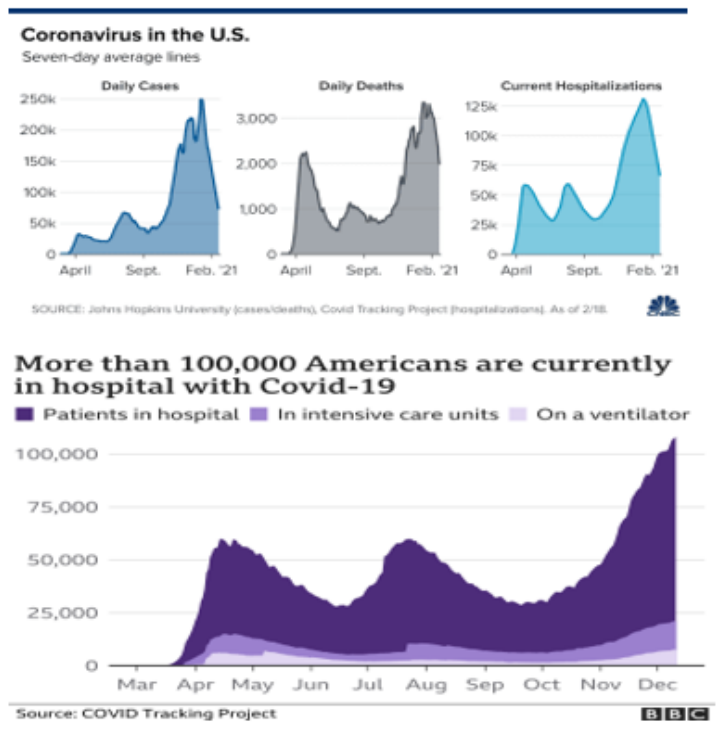

Figure 1 “John's Hopkins University (Cases/Deaths)" (n.d.) COVID Tracking Project (n.d.) 
In USA the rise in patients reporting and death rate was taking place in month of starting of april, month of august (union of summer and autumn) and end of december (union of autumn and winter).

- Status of United Kingdom in COVID time:
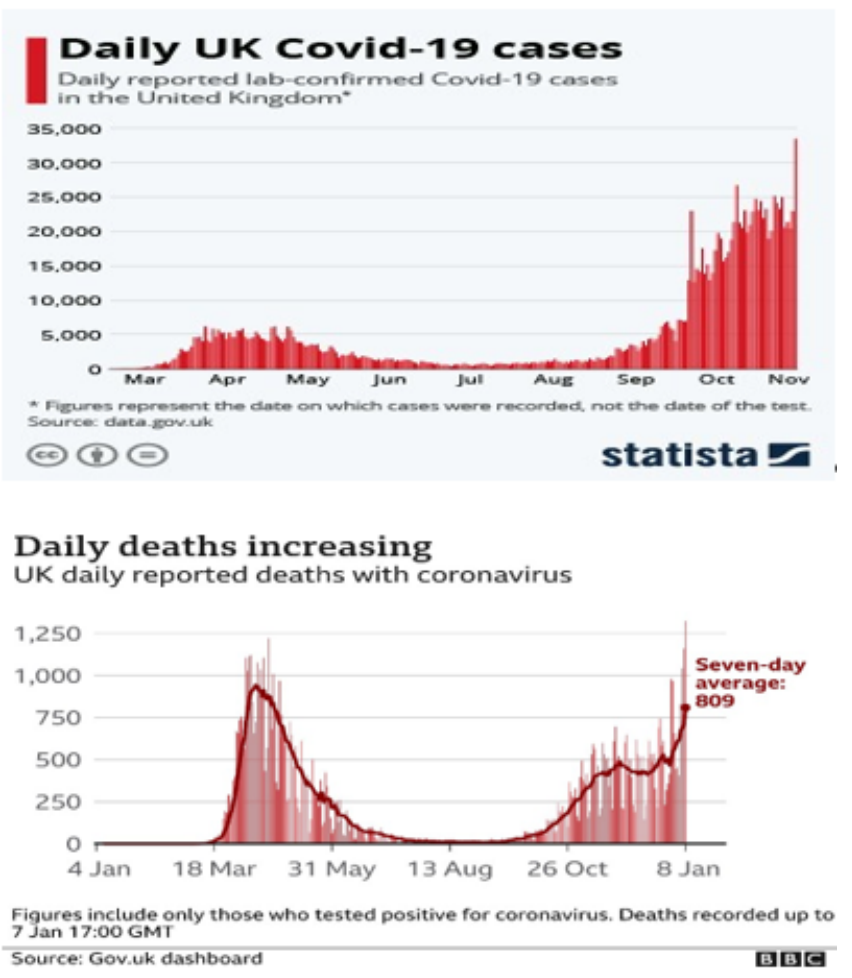

Figure 2 Statistica (n.d.), Gov.Uk Dashboard (n.d.)

In UK the peak of patient reporting and death rate was high in month of april (union of spring and summer) and end of november (union of autumn and winter).

- Status of Russia in COVID time

In Russia the peak of covid patient was reported in mid may which is union of winter and summer season in Russia.

- Status of Bharat in COVID times:

In Bharat the peak was found in cusp period of winter and spring.

It is clear that transition period makes the humans vulnerable for catching infections. In Charak Samhita a graded schedule for following diet patterns was suggested. In this perspective during each season the diet should be modified as per seasonal surge 


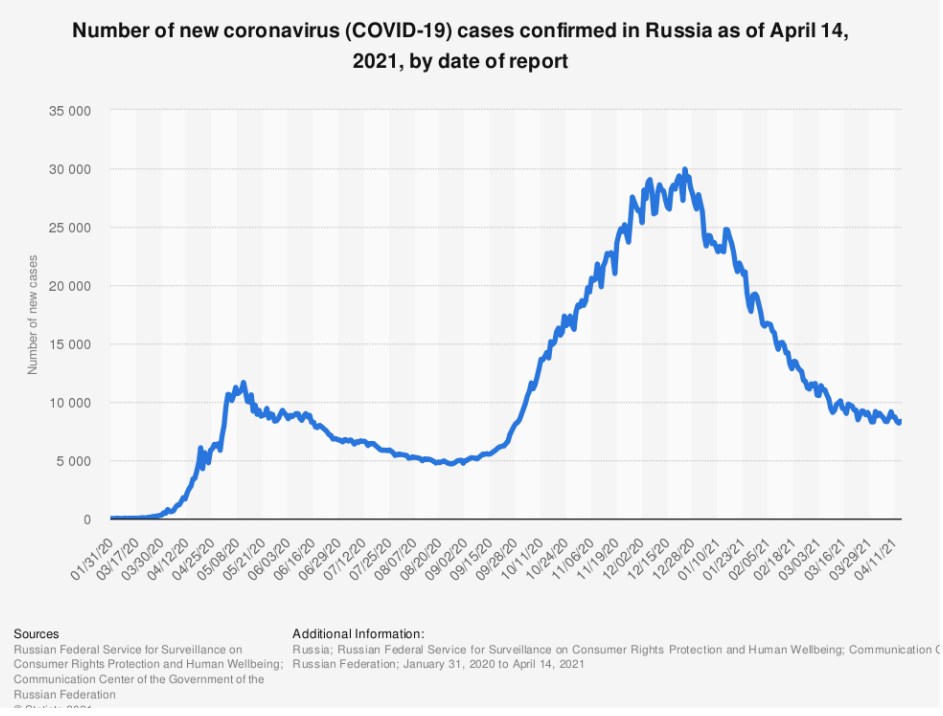

Figure 3 Russian Federal Service For Surveillance On Consumer Rights Protection, Russian Federal Service For Surveillance On Consumer Rights Protection And Human Wellbeing; Communication Center of The Government of The Russian Federation (n.d.)

\section{DAILY NEW CASES: ONLY ONE PEAK IN INDIA}

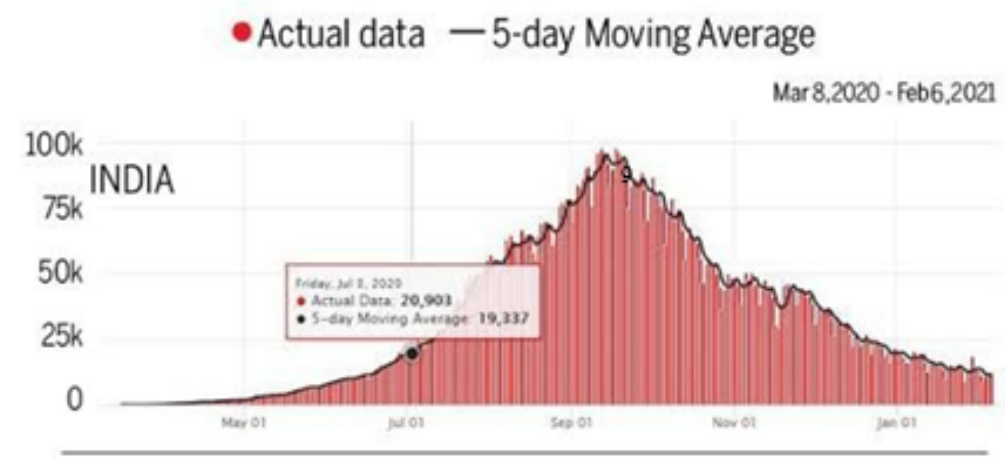

Figure 4 Times Of India. (n.d.)

or pacification of three humours(Vaat,Pitta,Cough)so that the harmony be ensured among the three. To achieve this goal,the person should gradually replace theme previous diet items with that of upcoming seasons. It had been recommended that one should change their diet over 1 week, that is, 7 days, slowly increasing the proportions of new seasons food from 0 to a $100 \%$ in order to maintain a healthy balance between the old and passing to the new and upcoming. For example, one might want to be linear about the rate of change about their diet: $1 / 7$ th of diet on first day consisting of new season food, 2/7th the second day, until the 7th day on which they'll eat $7 / 7$, that is, $100 \%$ new season food. This technique is named 
as Padanshik Tyag vidhi.Achary Charak says that this technique helps people in overcoming risk of any kinds of infections.Sharanghar Samhita suggested a very simple formula to take lighter food during change of season.

\section{CONCLUSION}

From the above data it could be concluded that impact of transition period is pretty clear in all over world. However, it's more convincingly depicted in Bharat. The reason is,that it has got all six seasons in it. Hence having clear cut visible cusps. Whereas in other three countries the climate remains almost same in terms of temperature or other parameters.

The other conclusion is that the remady suggested by Charak in the form of Padanshik Tyag may prove a boon to restore immunity during change of season for Bharat.The other countries may follow the simple formula of taking light diet, as is told in Sharangdhar Samhita.

\section{SUGGESTIONS}

1. Further research is required in the field to present it as a more evidence-based fact.

2. Diet patterns of varied countries should be explored.

3. Standardisation of Padanshik Tyag procedure may be done.

\section{REFERENCES}

Charak Samhita Navegaandhaaraniya/36-37. (2021). In and others (Ed.), (pp. 36-37). Retrieved from Http://Niimh.Nic.In/Ebooks/Ecaraka Last Accessed On 28/4/21.

Charak Samhita Tasyaashiteadhyaya/48 Chakrapaani. (2021). In and others (Ed.), . Retrieved from Http://Niimh.Nic.In/Ebooks/Ecaraka Last Accessed On 28/4/21.

COVID Tracking Project. (n.d.).

Gov.Uk Dashboard. (n.d.).

John's Hopkins University (Cases/Deaths). (n.d.). John's Hopkins University (Cases/Deaths), Covid Tracking Project(Hospitalizations). As Of 2/18.

Russian Federal Service For Surveillance On Consumer Rights Protection, Russian Federal Service For Surveillance On Consumer Rights Protection And Human Wellbeing; Communication Center Of The Government of The Russian Federation. (n.d.).

Shaaranghar Samhita Ch-3/29. (2021). Available from Ccras. Res. In. Last Accessed On 28/4/2021.

Statistica. (n.d.).

Times Of India. (n.d.). 